\title{
Bayesian age modelling applied to palaeoflood geochronologies and the investigation of Holocene flood magnitude and frequency
}

\author{
V.R. Thorndycraft, ${ }^{\prime}$ G. Benito, ${ }^{2}$ Y. Sánchez-Moya ${ }^{3}$ and A. Sopeña ${ }^{3}$
}

\begin{abstract}
A new methodology, based on Bayesian age modelling, is presented for the analysis of palaeoflood geochronologies and palaeodischarge data. Bayesian age models were developed, using the Oxcal radiocarbon calibration software, for the geochronologies of three palaeoflood sites in Spain, namely the Gaudalentín, Tagus and Llobregat rivers in SE, Central and NE Spain, respectively. The age-depth plots resulting from the applied Sequence models enabled the construction of flood magnitude-frequency plots through substitution of the original stratigraphic depth data with the associated minimum discharge quantified by hydraulic modelling. The age models presented demonstrate that a Bayesian approach for analyzing Holocene flood magnitude and frequency prevents the loss of geomorphic and hydrologic information inherent in radiocarbon frequency methods previously used in the analysis of palaeoflood data sets. Frequency approaches do not allow proper consideration of flood magnitude information and only incorporate those geomorphic units specifically dated. The Bayesian age models calculate modeled ages for undated units as well, so that all the individual flood events identified in the field can be incorporated and visualized in the data output. The palaeoflood age models therefore illustrate: $(\mathrm{I})$ the age range for clusters of palaeoflood events; (2) the number of events within each flood cluster, with an age estimate and palaeodischarge value for each event; and (3) the potential impact of discharge censoring on the record, for example the role of accommodation space infilling on the quantification of palaeodischarge. The methodology and results are briefly discussed within the wider context of fluvial palaeohydrology, in particular: (I) the role of Bayesian modelling in future fluvial palaeohydrology research; and (2) the value of bedrock gorge sites for investigating past flood-climate relationships, given the problems of deciphering allogenic and autogenic drivers in alluvial sedimentary records.
\end{abstract}

\section{Keywords}

Bayesian age modelling, flood magnitude and frequency, palaeofloods, radiocarbon dating, Spain

\section{Introduction}

Palaeoflood hydrology is the reconstruction of past flood magnitude and frequency using geomorphological evidence (Baker, 1987; Baker et al., 2002; Benito and Thorndycraft, 2005), commonly slackwater flood sediments preserved in bedrock gorge reaches (Benito et al., 2003a). The resulting data can provide information on the timing, magnitude and frequency of floods at specific reaches or rivers, with applications in global change research to investigate relationships between flooding and Holocene climatic variability (Ely et al., 1993) and/or land use impacts (Benito et al., 2010; Thorndycraft and Benito, 2006). This is of particular relevance given the short length of instrumental gauge station records, which may be of insufficient duration to identify trends in flood-climate relationships (e.g. Robson, 2002). The analysis of long-term records of the flood response to climate shifts at catchment, regional and global scales provide evidence for how future climatic variations might influence flood magnitude and frequency (Knox, 2000; Redmond et al., 2002).

Palaeoflood studies typically aim to establish the timing of each individual flood identified in the stratigraphic record, although in practice only a few can be dated because of a lack of datable material (e.g. organics) and the high costs of geochronological dating. An approach used to elucidate regional flood response to global change has been the analysis of frequency distributions of radiocarbon ages obtained from flood sediments from multiple rivers within hydroclimatically similar regions. For example, in SW USA, Ely (1997) used histogram plots based on radiocarbon ages obtained from slackwater flood sediments deposited on the valley margins of bedrock gorges during high flood stages. The dates were classified into 200 year bins and the numbers of dates per bin were used to identify the relative frequency of Holocene flooding. One problem with this approach is that the temporal resolution is too broad to reflect flood response to the decadal-scale variability of climate (Redmond et al., 2002), as evident from documentary flood records spanning the 'Little

'Royal Holloway University of London, UK

${ }^{2}$ Consejo Superior de Investigaciones Científicas, Spain

${ }^{3}$ Instituto de Geociencias CSIC-UCM, Spain

Received 22 December 2010; revised manuscript accepted 20 February 2011

Corresponding author:

V.R. Thorndycraft, Centre for Quaternary Research,

Department of Geography, Royal Holloway University of London, Egham TW20 0EX, UK.

Email: Varyl.Thorndycraft@rhul.ac.uk 

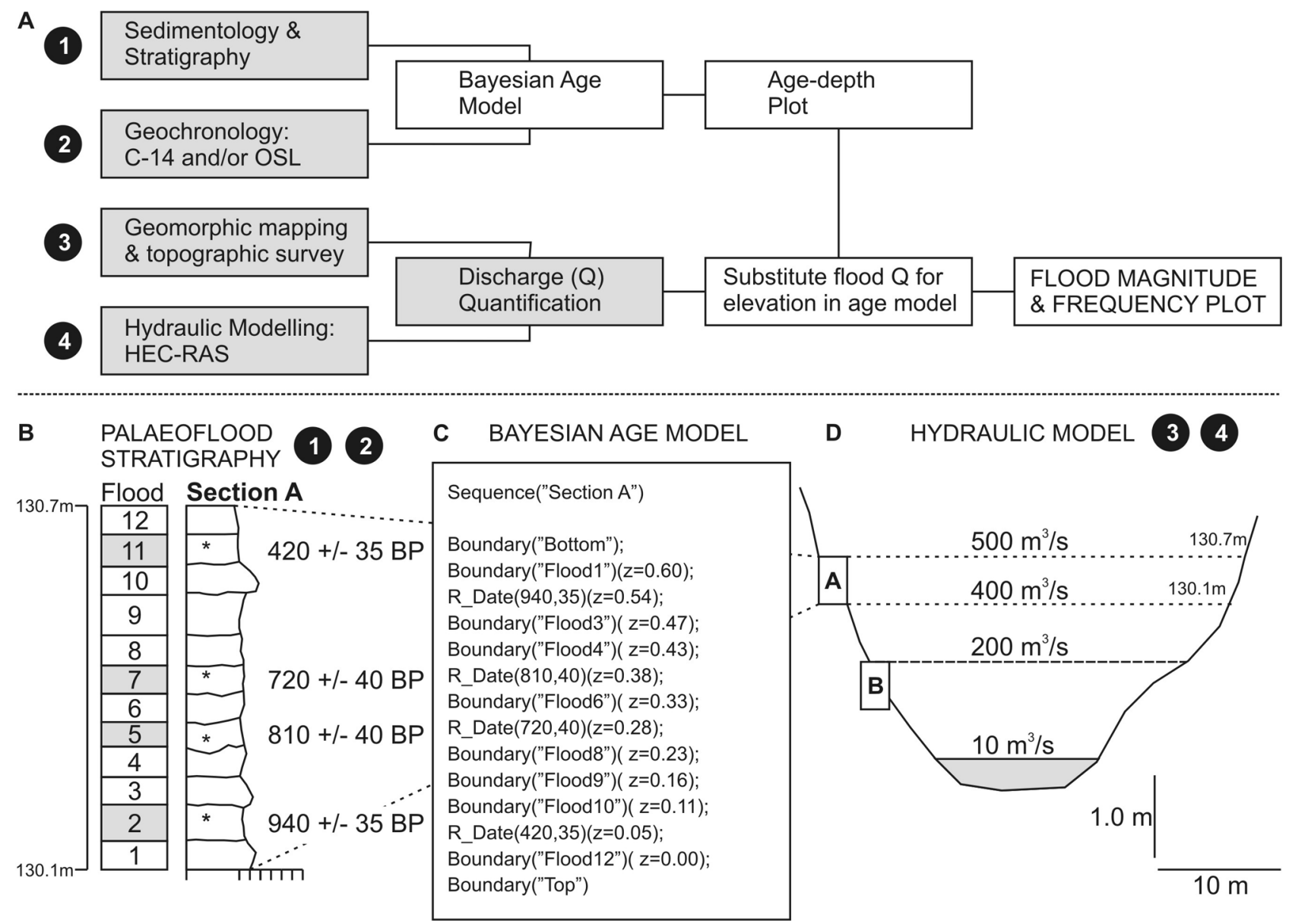

Figure I. (A) Schematic diagram illustrating the key methodological steps (I-4) in palaeoflood hydrological studies (grey boxes). The white boxes indicate the stages taken in the Bayesian age model and demonstrate how the modelling approach incorporates the prior information obtained during the palaeoflood research. (B) A hypothetical palaeoflood stratigraphy demonstrating the number of individual floods (I-I2) identified, with dated units highlighted (grey shading). (C) Nomenclature used in the age model for Section A (Figure 2B). Note that each undated flood unit is entered into the age model in addition to the R-Dates, the units separated using the boundary command. The depth of each stratigraphic unit is also entered where $z=$ the depth of the top of the stratigraphic unit. (D) Hypothetical cross-section and hydraulic modelling results showing the relationship of flood discharge to elevations O.D. at the base and top of Section A. The stratigraphy of the lower discharge threshold palaeoflood sequence (Section B) is not shown

Ice Age' in Catalonia (Barriendos and Martín-Vide, 1998; Llasat et al., 2005). This problem was believed to be overcome through the production and analysis of cumulative probability frequency (CPF) curves from multiple radiocarbon dates compiled for a region or country (Macklin et al., 2006), the curves produced using radiocarbon calibration software, such as OXCAL (Bronk Ramsey, 2008a). The resulting CPF curves comprise peaks and troughs, the peaks interpreted by some authors as an increase in flooding that, depending on the timeframe of investigation, may reflect regional climatic events or increasing human impact during the late Holocene (e.g. Macklin et al., 2006, 2010). However, Chiverrell et al. (2011) demonstrated flaws in this approach. Using the R-Simulate function in OXCAL they show that CPF peaks can give the wrong age; in the example discussed peaks are generated at 355, 315 and $230 \mathrm{cal}$. BC for a hypothetical flood event that occurred in $300 \mathrm{BC}$. This is due to the inherent errors in the dating process itself (Cook and van der Plicht, 2007; Scott, 2007), compounded by the shape of the radiocarbon calibration curve (Burr, 2007; Chiverrell et al., 2011; van der Plicht, 2007).

A further limitation of radiocarbon age frequency approaches is the inherent loss of geomorphic information. The key benefits of palaeoflood studies of slackwater flood deposits in bedrock gorges (cf. Baker, 1987; Baker et al., 2002; Benito and Thorndycraft, 2005) are that the number of (preserved) individual events can be determined from the stratigraphy (Benito et al., 2003a) and minimum discharge estimates for each palaeoflood event can be quantified through hydraulic modelling (Webb and Jarrett, 2002). However, a frequency distribution of radiocarbon ages limits the number of geomorphic (flood) events included in the analysis to only those that are radiocarbon dated; information on undated events and flood magnitude is lost. Referring to Figure 1, which summarises the methodology applied in this paper, the radiocarbon frequency approach only utilises methodological step 2; information from steps 1, 3 and 4 is effectively discarded.

Here we investigate Bayesian age modelling as a tool to counter this loss of geomorphic flood information in the analysis of Holocene palaeoflood data. A Bayesian age model is more robust than frequency approaches as it incorporates prior information in the model (Bronk Ramsey, 2008b), essentially the stratigraphic sequence and depth data, as well as the dating information. The aims of this paper are to: (1) illustrate the conceptual background and methodological approach for the application of Bayesian age modelling in the analysis of Holocene palaeoflood records; (2) demonstrate the application of Sequence Bayesian age models to previously 
published case studies; (3) compare the results of Bayesian and cumulative frequency analyses; and (4) discuss implications for the wider context of fluvial palaeohydrological research.

\section{Methodology}

Before describing the Bayesian age modelling approach used herein, it is worth outlining the key methodological steps taken in a typical palaeoflood study to demonstrate the geomorphic and hydrologic information that can be elucidated. These steps are illustrated in Figure 1A-D and comprise: (1) sedimentology and stratigraphy; (2) geochronology; (3) geomorphic mapping and topographic survey; and (4) hydraulic modelling. In step 1, the stratigraphy of the sedimentary sequence is determined to identify the number of individual flood events preserved at the section. Boundaries between flood events may be discerned by one or more of the following, depending on geomorphic setting: clay layers at the top of a unit (Benito et al., 2003a); the presence of bioturbation along an exposed sedimentary surface (Benito et al., 2003a); intercalation of non-flood sediments, e.g. colluvial (Benito et al., 2010), cave (Sheffer et al., 2003) or coarse-grained tributary sediments (Kochel and Baker, 1988). Geochronological control is then required to date the flood sequence, usually through either AMS radiocarbon dating (Jull, 2007) of organic materials transported in the flood (e.g. twigs, seeds or charcoal) and/or Optically Stimulated Luminescence (OSL) dating of quartz grains, increasingly applied in fluvial (Rittenour, 2008; Rodnight et al., 2005, 2006) and palaeoflood studies (Benito et al., 2011). Topographic surveys of multiple cross-sections are carried out, or a digital elevation model (DEM) of the study reach is created (step 3) using, for example, topography obtained from LiDAR survey combined with detailed field survey of the sites of flood deposition (Casas et al., 2006). Finally, hydraulic modelling is carried out (step 4) to quantify minimum palaeodischarge estimates for the different flood units identified in step 1. A onedimensional step backwater model, such as HEC-RAS, is usually used (Webb and Jarrett, 2002) because of the relatively simple flow circulation in bedrock gorges and the uncertainties associated with estimating roughness coefficients for past flood events; uncertainties that increase in the case of two-dimensional hydraulic models. A range of flood discharges are routed through the study reach and the resulting floodwater elevations produced by the model are matched to the elevation of the flood deposits (Figure 1D). The final output of these steps, therefore, is data on the magnitude and frequency of flooding, information that can be organised in relation to changing flood discharge thresholds through time (Benito et al., 2004).

A review of Bayesian age modelling was published by Bronk Ramsey (2008b). The main reason a Bayesian methodological approach can be considered more robust than using CPFs, for example, is that it incorporates the stratigraphic sequence and depth data in the model, as well as dating information in the form of probability distribution functions that indicate the likelihood that a sample has a particular age. A variety of deposition models have been developed to deal with a range of sedimentation processes (e.g. variable rates of sedimentation or episodic sedimentation events). Owing to the episodic nature of slackwater flood deposition (Benito et al., 2003a) the Sequence model was considered to be most appropriate for palaeoflood case studies. The Sequence model states that the specified events are in a known order (determined from the stratigraphy) but no specific use is made of the depth information (see table 1 in Bronk Ramsey, 2008 b), i.e. the age model is constructed using only the dating evidence and stratigraphic order of events. The OxCal software does, however, enable stratigraphic depth to be entered in the Sequence model. Whilst not directly used in the modelling this function enables the output of an age-depth diagram. A hypothetical example of data input using OxCal, for a Sequence model applied to palaeoflood deposits, is shown in Figure 1C. As slackwater deposition is episodic and the sedimentation events are punctuated by unknown periods with no sedimentation, each individual flood unit identified in the stratigraphy was separated by using the boundary function. This means that, for each undated flood unit, a modelled age was produced. The specific prior information needed for each age model was the following: (a) the number of individual flood units, which determined the number of boundaries and events in the model; (b) the radiocarbon dating information and related flood unit number; and (c) the depth $(z)$ of the top of each flood unit - the upper contact was used as this is the elevation that must have been inundated by the floodwaters. The depth information (z), whilst not used in the Sequence age model was inputted to produce an age-depth plot (e.g. Figure 3) and subsequently, through substitution of the elevation above datum and modelled discharge data, a flood magnitude-frequency plot can be generated (e.g. Figure 4).

This approach was carried out for palaeoflood sequences from three previously published sites: Sections ES1 and ES/2 from the Guadalentín basin (Benito et al., 2010); Sections 1.2 and 1.5 of the Tagus River (Benito et al., 2003b); and the Pont de Vilomara site of the Llobregat River (Thorndycraft et al., 2005). These palaeoflood records were chosen because of their contrasting number, and spacing, of radiocarbon dates (see Table 1 for sample details) and different geomorphic settings (Figure 2). The Guadalentín section is comprised of an approximately $5.5 \mathrm{~m}$ sequence of slackwater flood deposits with two colluvial deposits indicating flood sedimentation hiatuses or a lack of large flood occurrence. Dating control was provided by six dates spanning the last 1000 years (Figure 3 and Table 1). This is, therefore, a good site to look at variations in flood frequency in relation to climatic variability during the last millennium, with a hydrological response enhanced by historical land-use changes. Discharge estimation of the palaeofloods may, however, contain errors owing to the presence of alluvial channel sediments at the site (Benito et al., 2010). By contrast, the Tagus sections are located on raised benches within a stable bedrock gorge and here Benito et al. (2003b) were able to quantify changing flood magnitude through the Holocene, though in this paper we focus on the early- to mid-Holocene record. The Llobregat section is located in a valley side alcove $c .17 \mathrm{~m}$ above the river bed and is included herein to provide an example of a section where dating control for the complete section is poor, as only the two middle units of an eight-flood sequence were radiocarbon dated (Thorndycraft et al., 2005).

Table 2 presents an overview of age model performance through the $A_{\text {model }}$ and $A_{\text {overall }}$ indices generated in Oxcal. For the Guadalentín section, the statistical performance of the initial model (model 1, Table 2) was lower than for the other sites although at 65.8 the $A_{\text {overall }}$ index value is above the statistically significant threshold of 60 (Bronk Ramsey, 2008b). The reason for the lower index value is most likely due to the overlap of the calibrated age ranges between c. 1000 and 800 cal. BP, with some of the R-Date $(1050,50)$ age range falling earlier than dates from older floods preserved lower in the sequence. Alternative 

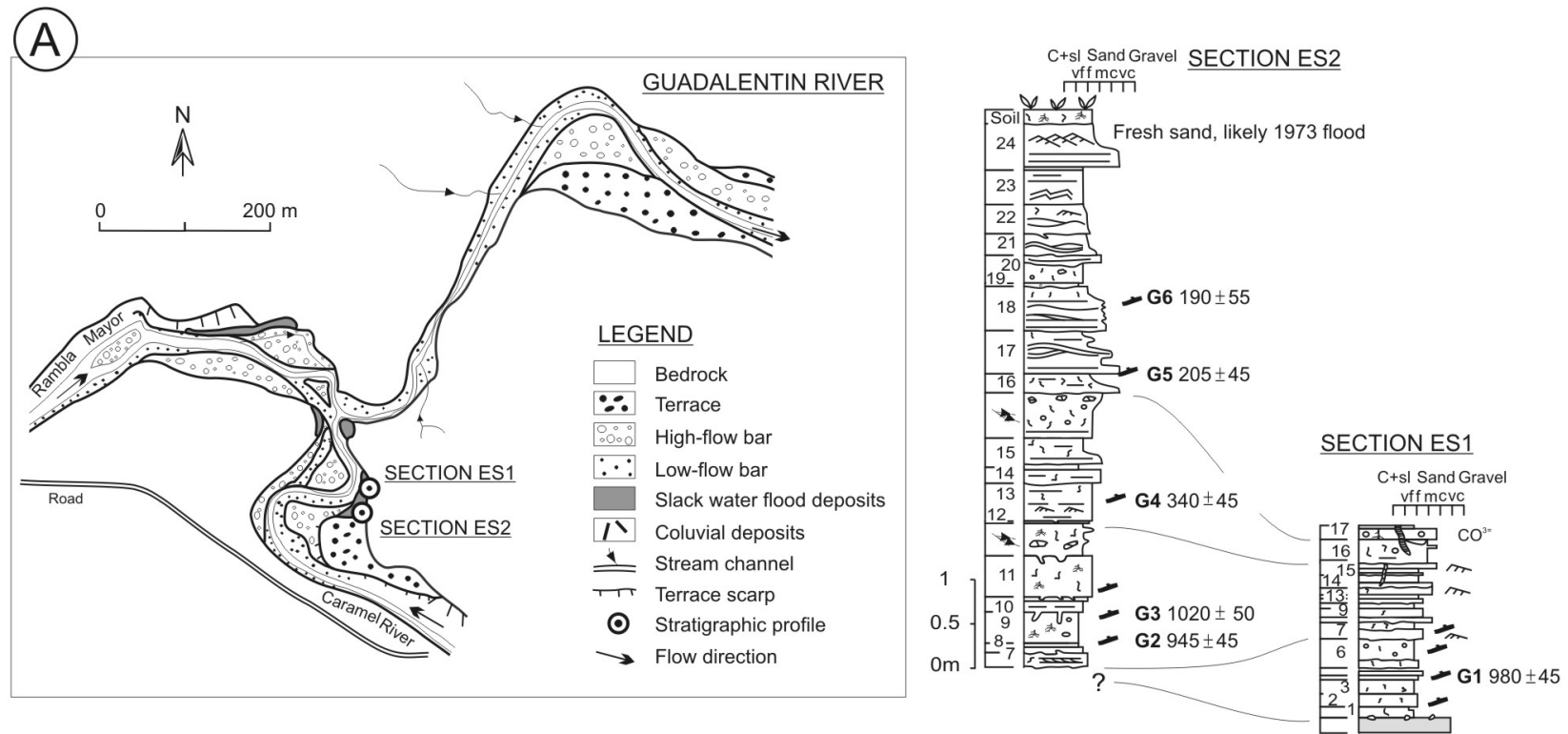

(B)
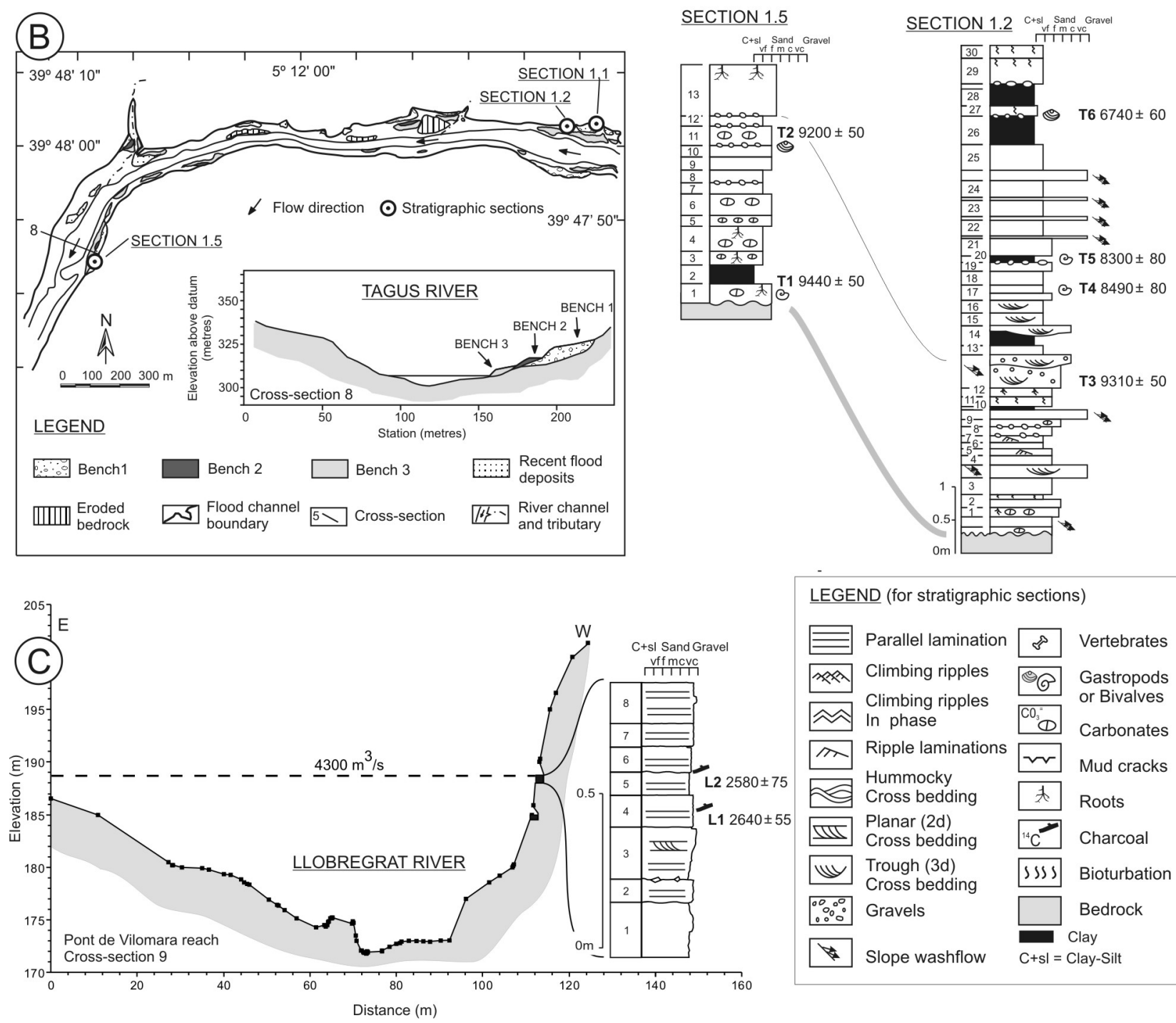

Figure 2. Geomorphic settings and stratigraphy of the three study reaches discussed in the paper: (A) Guadalentín; (B) Tagus; and (C) Llobregat. The figures are modified from (A) Benito et al. (2010); (B) Benito et al. (2003b); and (C) Thorndycraft et al., (2005)

models were carried out to see if model performance could be increased (Table 2). There was a statistical improvement for both models 3 and 4, which involved the removal of R-Date $(1020,50)$ in the case of model 3 and the additional removal of R-Date
$(120,55)$ for model 4 . However, despite the increase in $A_{\text {overall }}$ to 86.8 (model 3) and 83.3 (model 4) it was felt that the reduced prior information contained within these models did not warrant their adoption ahead of model 1 , the results of which are 


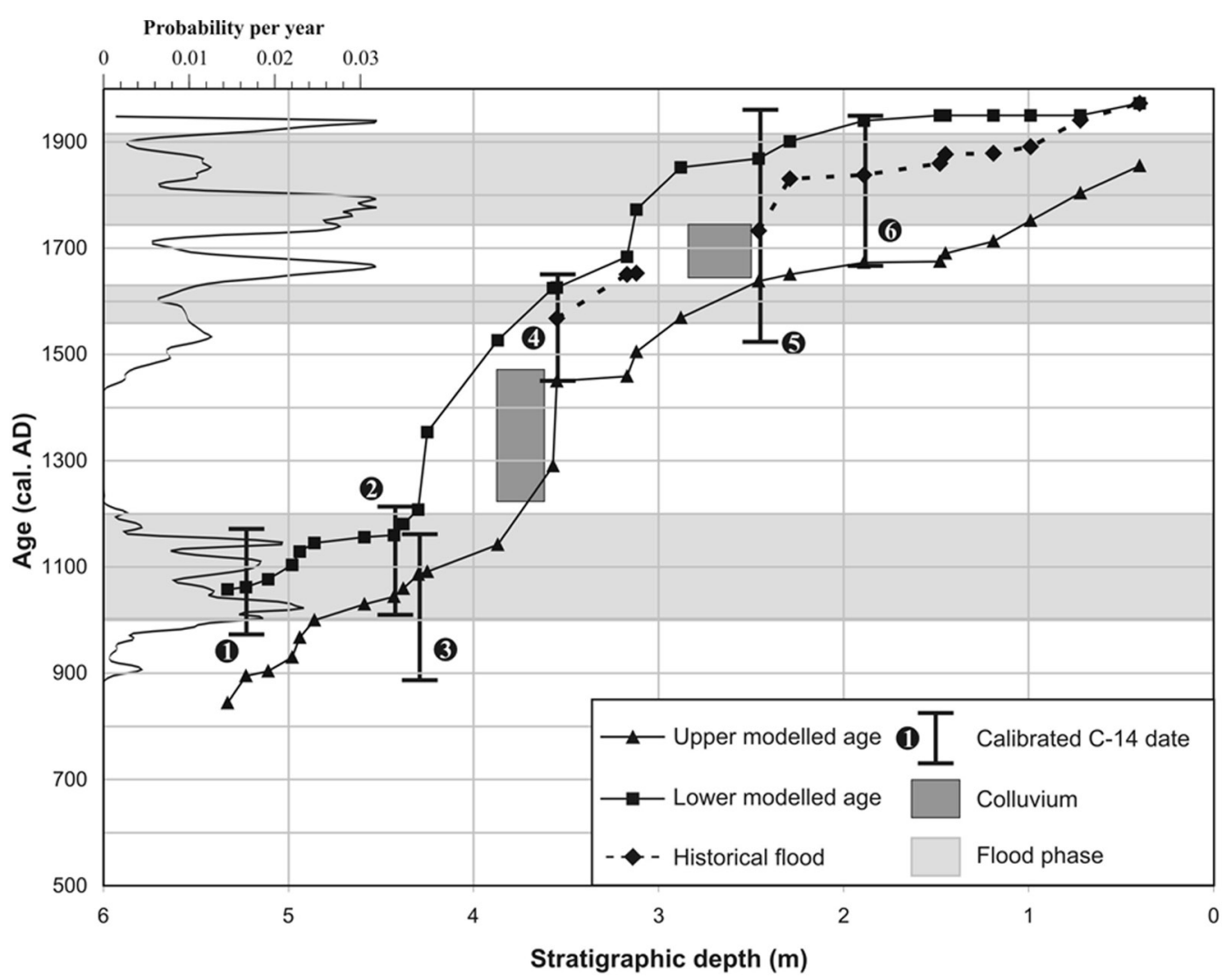

Figure 3. Bayesian age-depth model for the Guadalentín site plotted alongside the two-sigma age ranges of the radiocarbon dates (numbered according to Table I). Also presented is: a CPF curve produced by a sum probability plot (also in Oxcal) of the six radiocarbon dates from the site; and the documentary flood record discussed in Benito et al. (2010)

discussed below. There were no statistical issues with the two Tagus or Llobregat models with $A_{\text {overall }}$ values of 103.6, 97.8 and 103.9, respectively (Table 2).

\section{Results and discussion}

The results of the Guadalentín model are presented in Figure 3. The key stratigraphic section for the site is a c. $5.5 \mathrm{~m}$ sequence of slackwater flood deposits located upstream of the confluence of the Caramel and Rambla Mayor rivers which join at the entrance to a narrow limestone gorge (Figure 2). The aggraded sequence reflects significant within-channel sedimentation at this locality, probably in response to increasing sediment loads resulting from land-use impacts. As such this palaeoflood site does not provide robust discharge estimation for all the palaeoflood events identified in the stratigraphy (Benito et al., 2010). It does, however, enable preservation of a sequence of 24 flood events spanning the last c. 1000 years (Benito et al., 2010) making the sequence a good locality for investigating late-Holocene flood frequency using the Bayesian approach. The results of the age model are presented in Figure 3, the graph produced in Excel following export of the tabulated Oxcal data to enable the age-depth model to be presented alongside the historical flood record (Benito et al., 2010) and a CPF curve (cf. Johnstone et al., 2006) produced from the six radiocarbon dates.

The modelled ages for each individual palaeoflood unit identified in the sequence are presented alongside the two sigma age range of the six radiocarbon dates (indicated by the upper and lower calibrated ages). Where the curves for the upper and lower modelled ages flatten there is an increase in the frequency of flood events, for example between 5.4 and $4.2 \mathrm{~m}$ where a sequence of ten flood units is preserved in the stratigraphy. The lower modelled ages pre-dating AD 1000 are ignored in the interpretation as the lower age is from a charcoal sample (Table 1) so it is unlikely that floods would have occurred prior to the lower calibrated age of Date 1. This means that this phase of flooding can be interpreted to have occurred between AD 1000 and 1200 (Figure 3). The model deals with R-Date $(1020,50)$, the older overlapping age range, which could be due to the reworking of slightly older charcoal or the probabilistic errors associated with the dating itself (Chiverrell et al., 2011), by extrapolating the age to fit with the rest of the sequence, so the modelled ages are younger (from $\mathrm{AD} 1086$ to 1208) than the two sigma calibrated age range of the radiocarbon date ( $\mathrm{AD} 895-1155)$. Note that in the $\mathrm{CPF}$ approach the entire range of this date is included in the CPF curve despite this not being a geomorphologically sensible interpretation.

Between 4.2 and $2.6 \mathrm{~m}$ depth there are two colluvial units separated by three flood events centred on cal. AD 1450-1680 and corresponding to the 'Little Ice Age'. There is then increased preservation of flood sediments during the eighteenth and nineteenth centuries. Note here that the gaps in the $\mathrm{x}$-axis between successive flood events are greater reflecting the increased thickness of sediments in each individual flood unit, believed to reflect a land-use signal on catchment disturbance and the flood record (Benito et al., 2010). The gap between the lower and upper modelled ages on the y-axis are also greater reflecting the age uncertainties and problems of radiocarbon dating over the last 300 years (Trumbore, 2000). Benito et al. (2010) correlated the documentary flood record for the Guadalentín basin with the palaeoflood record. The post AD 1500 documentary floods are also shown 
Table I. Summary information for the radiocarbon samples used in the Bayesian age models, with the sample IDs relating to the numbers on Figures 3-5

\begin{tabular}{|c|c|c|c|c|c|}
\hline River and sample ID & Lab code & Material dated & ${ }^{14} \mathrm{C}$ method & Date & $\begin{array}{l}\text { Calibrated age } \\
\text { range (2-sigma) }\end{array}$ \\
\hline Guadalentín-I & UZ-4597/ETH-244IO & Charcoal & AMS & $980 \pm 45$ & AD $980(95.4 \%)$ AD I I 90 \\
\hline Guadalentín-2 & UZ-4598/ETH-244I I & Charcoal & AMS & $945 \pm 45$ & AD $1000(95.4 \%)$ AD 1210 \\
\hline Guadalentín-3 & UZ-4599/ETH-244I 2 & Charcoal & AMS & $1020 \pm 50$ & AD 890 (95.4\%) AD I I 60 \\
\hline Guadalentín-4 & UZ-4600/ETH-244I3 & Charcoal & AMS & $340 \pm 45$ & AD I $450(95.4 \%)$ AD 1650 \\
\hline Guadalentín-5 & UZ-460I/ETH-244I 4 & Charcoal & AMS & $205 \pm 45$ & $\begin{array}{l}\text { AD } 1630(27.2 \%) \text { AD } 17 \mid 0 \\
\text { AD } 1720(54.3 \%) \text { AD } 1890 \\
\text { AD } 1910(13.9 \%) \text { AD } 1960\end{array}$ \\
\hline Guadalentín-6 & UZ-4659/ETH-2468I & Charcoal & AMS & $190 \pm 55$ & AD $1630(95.4 \%)$ AD 1960 \\
\hline Tagus-I & Beta-0983I4 & Mollusc shell & AMS & $9440 \pm 50$ & $\begin{array}{l}9150 \mathrm{BC}(13.4 \%) 8950 \mathrm{BC} \\
8900 \mathrm{BC}(82.0 \%) 8550 \mathrm{BC}\end{array}$ \\
\hline Tagus-2 & Beta-0983I5 & Mollusc shell & AMS & $9210 \pm 50$ & $8560 \mathrm{BC}(95.4 \%) 8280 \mathrm{BC}$ \\
\hline Tagus-3 & GrA-3000 & Charcoal & AMS & $9310 \pm 50$ & $\begin{array}{l}8730 \mathrm{BC}(89.0 \%) 8410 \mathrm{BC} \\
8400 \mathrm{BC}(6.4 \%) 8330 \mathrm{BC}\end{array}$ \\
\hline Tagus-4 & GrA-3I78 & Gastropod shell & AMS & $8490 \pm 80$ & $7680 \mathrm{BC}(95.4 \%) 7320 \mathrm{BC}$ \\
\hline Tagus-5 & GrA-3I77 & Gastropod shell & AMS & $8300 \pm 80$ & $\begin{array}{l}7540 \mathrm{BC}(93.5 \%) 7120 \mathrm{BC} \\
7100 \mathrm{BC}(1.9 \%) 7080 \mathrm{BC}\end{array}$ \\
\hline Tagus-6 & Beta-098317 & Mollusc shell & Conv. & $6740 \pm 60$ & $5740 \mathrm{BC}(95.4 \%) 5530 \mathrm{BC}$ \\
\hline Llobregat-I & UZ-4523/ETH-23673 & Charcoal & AMS & $2640 \pm 55$ & $\begin{array}{l}930 \mathrm{BC}(88.5 \%) 750 \mathrm{BC} \\
690 \mathrm{BC}(2.3 \%) 660 \mathrm{BC} \\
640 \mathrm{BC}(3.2 \%) 590 \mathrm{BC}\end{array}$ \\
\hline Llobregat-2 & UZ-4524/ETH-23674 & Charcoal & AMS & $2580 \pm 75$ & $\begin{array}{l}900 \mathrm{BC}(1.7 \%) 870 \mathrm{BC} \\
840 \mathrm{BC}(88.8 \%) 480 \mathrm{BC}\end{array}$ \\
\hline
\end{tabular}

AMS, samples dated by the Accelerator Mass Spectrometry method (Jull, 2007); Conv., conventional dating (Cook and van der Plicht, 2007).

Table 2. Statistical output data for the Bayesian age models described in the paper. The comments column indicates Agreement indices (A) in italics (where below 60) and highlights which individual dates were removed from Models 2-4. Note that Model I was retained as the best model for the Guadalentín sequence as it passed the significant $A_{\text {model }}$ and $A_{\text {overall }}$ thresholds of 60 and contained greater geomorphic information than the statistically better performing Model 4

\begin{tabular}{|c|c|c|c|c|}
\hline River/Section & Model & $A_{\text {model }}$ & $A_{\text {overall }}$ & Comments \\
\hline \multirow[t]{4}{*}{ Guadalentín } & I & 65.6 & 65.8 & $\begin{array}{l}R \_ \text {Date }(I 020,50), A=4 I .7 \\
R \_D a t e(I 20,55), \text { may extend out } \\
\text { of range }\end{array}$ \\
\hline & 2 & 42.7 & 48.1 & $\begin{array}{l}\text { R_Date }(I 20,55) \text { removed from } \\
\text { model } \\
R \_D a t e(980,45), A=47.7 \\
R \_D a t e(I 020,50), A=40.5\end{array}$ \\
\hline & 3 & 85.6 & 86.8 & $\begin{array}{l}\text { R_Date }(1020,50) \text { removed from } \\
\text { model }\end{array}$ \\
\hline & 4 & 82.1 & 83.3 & $\begin{array}{l}\text { R_Date }(1020,50) \text { \& R_Date } \\
(120,55) \text { removed from model }\end{array}$ \\
\hline Tagus/Section I.I/I.2 & - & 103.6 & 103.6 & - \\
\hline Tagus/Section I.5 & - & 97.6 & 97.8 & - \\
\hline Llobregat & - & 102.2 & 103.9 & - \\
\hline
\end{tabular}

in Figure 3 and fit between the upper and lower modelled ages, with a skew towards the upper ages, perhaps reflecting the lag in the system of the dated charcoal assuming the assignment of historical floods to the specific sedimentary flood units is correct.

To summarise the Guadalentín site, the Bayesian age model is more robust than the CPF approach as it takes account of the calibrated age overlap of R-Date $(1020,50)$ and is less sensitive to the effects of the calibration curve which controls the peaks and troughs of the CPF curve that, subsequently, make it difficult to interpret on sound geomorphological grounds. For example, the CPF curve for the period cal. AD $900-1200$ is characterised by peaks and troughs; from cal. AD 1500 the main peak in probability coincides with the colluvial hiatus and does not reflect the historic flood record. In contrast to the CPF curve the age-depth model illustrates the interpreted environmental history of the site, as reported by Benito et al. (2010), with: a higher frequency of floods centred around cal. AD 1100; some isolated 'Little Ice Age' floods in the second half of the seventeenth and eighteenth centuries; followed by increased frequency of flooding and catchment disturbance producing thicker sedimentary sequences from the nineteenth century. The hydraulic modelling results for the site, combined with the sedimentology, indicate higher energy conditions during the late nineteenth century floods (Benito et al., 2010) and it is likely that flood magnitude of the nineteenth century floods was larger than those occurring during the eleventh and twelfth centuries. 


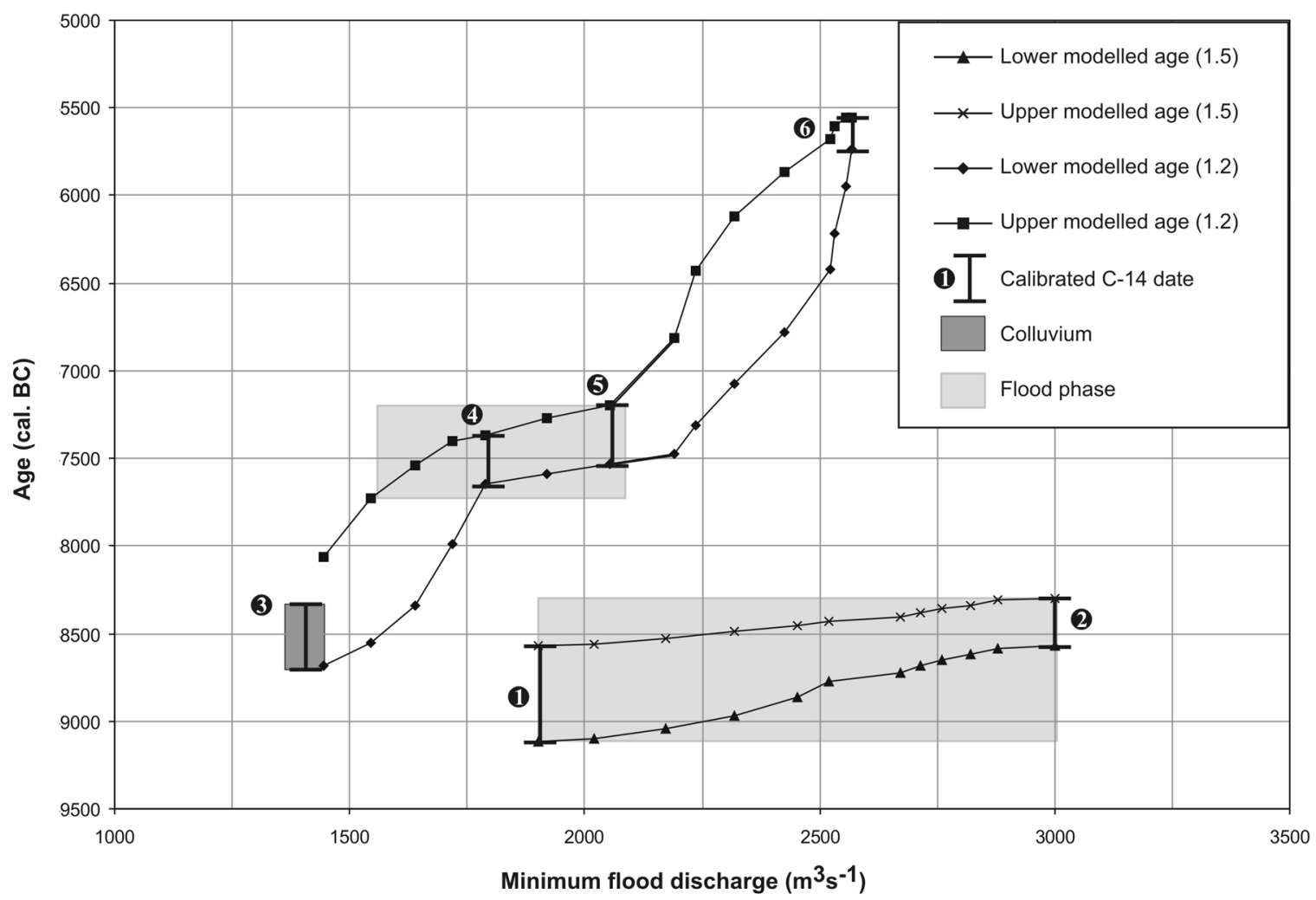

Figure 4. A flood magnitude-frequency diagram for palaeoflood sediments of the Tagus River (Sections I.I/I.2 and I.5), generated from a Bayesian age model, plotted alongside the two-sigma age ranges of the radiocarbon dates (numbered according to Table I). Note that flood deposit elevation has been replaced with the discharge estimate from hydraulic modelling.

More precise discharge estimates were obtained for the Tagus River at the Puente de Arzobispo reach (Benito et al., 2003 b), so for this site a flood magnitude-frequency plot has been produced (Figure 4). The more recent sediments of Section 1.2 (younger than 7000 cal. BC) do not have sufficient dating control to ascertain a distinct phase of increased flood frequency as there is only one age at the top of the sedimentary sequence. Therefore, the modelled ages are distributed evenly between 7200 and $5750 \mathrm{cal}$. BC and the magnitude-frequency plot is characterised by vertical trending curves for the upper and lower modelled ages (Figure 4). By contrast, the curves for Section 1.5 demonstrate an elongated, horizontal distribution reflecting a greater frequency of events, with 12 large-magnitude floods occurring between between 9100 and $8250 \mathrm{cal}$. BC. It should be noted, however, that the modelled ages themselves are dependent on the ages obtained from the two radiocarbon samples at the top and bottom of the sedimentary sequence. As Chiverrell et al. (2009a) demonstrate, multiple radiocarbon dates from the same stratigraphic unit can yield contrasting ages. Should one of the ages from Section 1.5 be erroneous then so too the interpreted flood frequency. This highlights the need for multiple dating of the same flood units as well as increasing the numbers of dated units. In practical terms in palaeoflood studies this can be problematic owing to the lack of availability of organic materials for radiocarbon dating. Recourse may also be made to Optically Stimulated Luminescence (OSL) dating, where new techniques of single grain analysis (Rittenour, 2008) may now enable improved dating of quartz grains within slackwater flood deposits (e.g. Benito et al., 2011).

A constrained period of flooding is also hypothesised for the lower part of Section 1.2 (Figure 4). The modelled ages of the older units are pulled towards the basal age provided by a dated colluvial unit underlying the flood sediments. In terms of the hypothesised age range, therefore, it has been assumed that the most realistic ages are towards the two dates T4 and T5, therefore the age bracket for this phase of flooding is $7750-7200 \mathrm{cal}$. BC. Thus the age-model illustrates two phases of increased flood frequency in the early Holocene dated to 9100-8250 cal. BC and $7750-7200$ cal. BC, compared with $8905-8280 \mathrm{cal}$. BC and 7680-6835 cal. BC hypothesised using a CPF approach (see the review by Thorndycraft and Benito, 2006). The differences in the age constraints for these flood phases reflect the greater transparency within Figure 4 as opposed to the frequency curve of Thorndycraft and Benito (2006).

The other advantage of Figure 4 over a CPF curve is that flood discharge data are illustrated, here presented along the $\mathrm{x}$-axis. The magnitude information shows two key features. First, the increasing discharge threshold needed for deposition of each successive unit is clearly evident, with over $1000 \mathrm{~m}^{3} / \mathrm{s}$ difference between the minimum discharge estimates of the upper and lower flood units at both sites. This reflects the fact that each flood unit (and point on the graph) represents the minimum discharge required for a flood to reach the sediments, so the discharge indicated on Figure 4 is a minimum estimate and the real discharge will have been greater by an unknown amount. Nevertheless, it is evident that the largest flood magnitudes most likely occurred during the earliest flood-rich phase, namely at 9100-8250 cal. BC, with discharges reaching at least $2600-3000 \mathrm{~m}^{3} / \mathrm{s}$ for the largest events.

The issue of accommodation space and flood bench morphology influencing the reconstructed discharge thresholds as described for the Tagus River is avoided where slackwater flood sediments are deposited in smaller accommodation spaces within, for example, valley side alcoves (e.g. Sheffer et al., 2008; Thorndycraft et al., 2005). This is the case for the Pont de Vilomara 


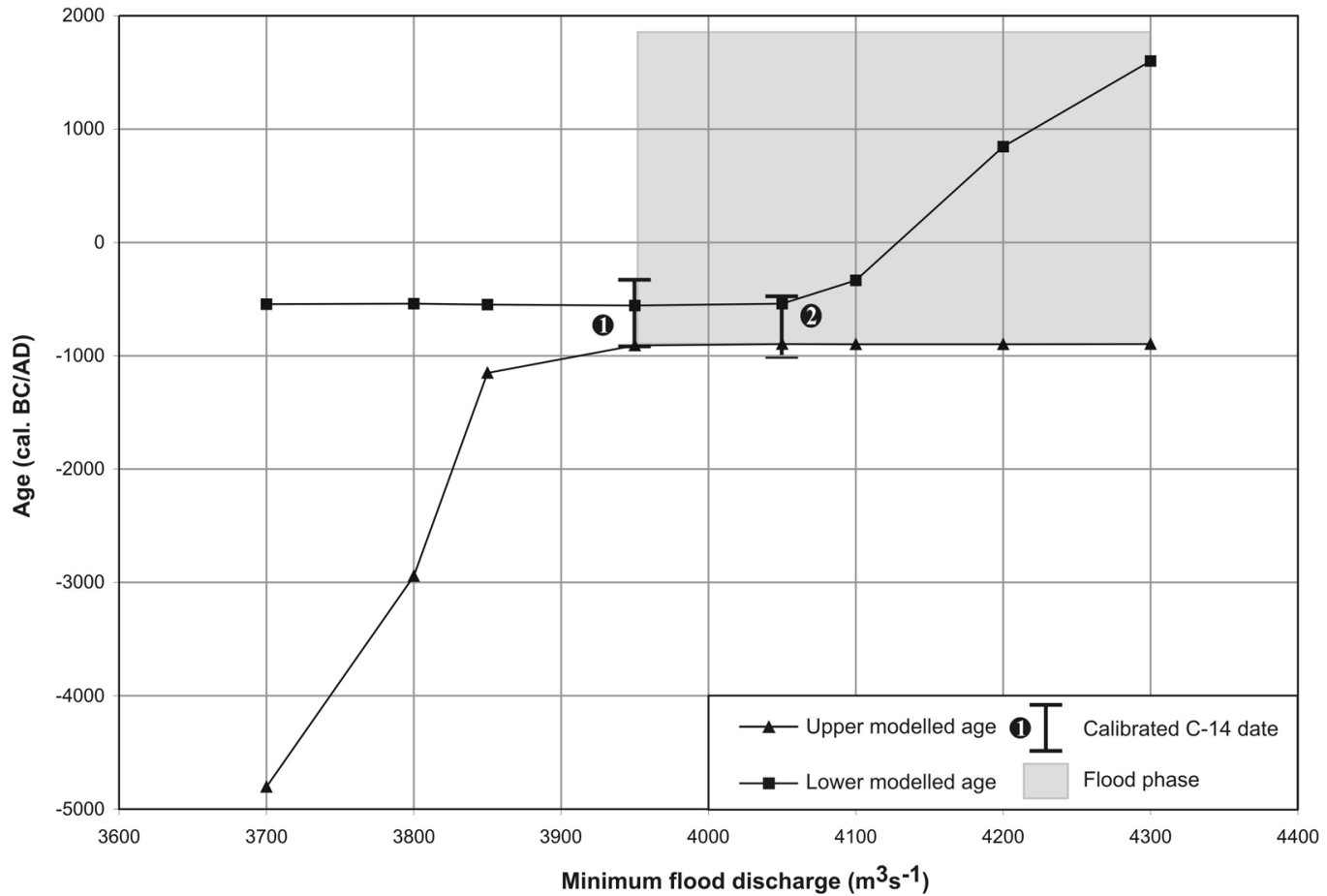

Figure 5. A flood magnitude-frequency diagram for the Llobregat palaeoflood deposits at Pont de Vilomara plotted alongside the twosigma age ranges of the radiocarbon dates (numbered according to Table I). Owing to a lack of available organics the site exhibits a poorly constrained age model. However, the site identifies two extreme events associated with the 2650 BP cold event (Van Geel et al., 1998) and for flood hazard studies shows the occurrence of five extreme events, much larger than any flood of the instrumental record, between 900 cal. BC and AD 1900

site of the Llobregat River (see Figure 2) discussed by Thorndycraft et al. (2005). Here, a 0.9 m thick sequence contained within a small valley side rock alcove preserves eight flood units. Again, the associated discharges modelled for each flood unit reflect minimum flood discharges but the volume and thickness of the flood sediments are small and do not influence the local discharge threshold as much. The age-magnitude plot for this section is shown in Figure 5. Whilst the discharge values are constrained to $3700-4300 \mathrm{~m}^{3} / \mathrm{s}$, greater than the largest flood on record, the 1971 event that reached $1650 \mathrm{~m}^{3} / \mathrm{s}$, the Bayesian age model clearly indicates the need for more radiocarbon ages to date the six undated flood events. As the only dateable material was obtained from the middle flood units the modelled ages show a wide range of ages, insufficient to infer any specific controlling climatic driver, though it can be stated that the two dated events occur in relation to a regionally cooler climatic phase, and with regards flood hazards it is evident that at least five extreme magnitude floods of over $3950 \mathrm{~m}^{3} / \mathrm{s}$, larger than any event during the instrumental period, have occurred between cal. 900 BC and AD 1900 (see the grey shaded area in Figure 5).

To summarise the three sites presented, therefore, it can be seen that there are strengths and limitations of each, in relation to their magnitude-frequency record, that are controlled by the specific geomorphic setting of the sites of deposition and the availability of organic materials for radiocarbon dating. For the Guadalentín site (Figure 3) the discharge data were compromised because of channel aggradation, although it is likely that flood magnitudes during the 'Little Ice Age' were larger than those of the earlier flood-rich period dated to cal. AD 1000-1200. By contrast the Tagus and Llobregat sites were more appropriate for the construction of new flood magnitude-frequency plots (Figures 4 and 5, respectively), where the Bayesian approach enabled modelling the age of undated flood units as well as the incorporation of hydraulic modelling results through substitution with deposit elevation above datum. The results, therefore, demonstrate the value of Bayesian age modelling for maintaining the hydrologic and geomorphic information obtained during the original field and flood modelling investigations.

Many palaeoflood studies use multiple sites of slackwater deposition along a study reach, with correlations made between them, or they may also include other types of palaeostage indicators depending on their preservation in the field. Whilst slackwater deposits such as those discussed in this article provide minimum palaeodischarge estimates, there may also be upper bound thresholds identified in the field. For example, geomorphic surfaces, such as terraces (e.g. Levish, 2002), dated to $x$ years BP and with no physical evidence of flooding since that age, would indicate a maximum flood discharge level that had not been exceeded during the last $x$ years. This additional palaeostage information could also be incorporated into the Bayesian age modelling framework, for example by adding a dated upper bound threshold as an event in a Sequence model, in a similar manner to the interrogation of Holocene terrace incision events in the Ribble Valley, NW England (Chiverrell et al., 2009a, 2009b). Such models would allow the testing of multiple hypotheses associated with the available geomorphic flood evidence along a particular reach of river.

Finally, the Bayesian age modelling approach described in this article has wider implications with regards current research in fluvial palaeohydrology. For example, it raises concerns over the use of CPF curves as hydroclimatically sensitive proxies (cf. Macklin et al., 2006) or for the quantification of allogenic and autogenic controls in fluvial systems (Macklin et al., 2010). This is due to the loss of geomorphic information and in particular the inability of frequency curves to differentiate between the range of flood magnitudes which may be responsible for the occurrence of a geomorphic event preserved in the sedimentary record. This 
latter point is especially critical given the non-linearity of fluvial systems and self-organized criticality (SOC) in river basins, which Van De Wiel and Coulthard (2010) suggest may prevent links to be made between cause and effect in river systems. Therefore, future fluvial palaeohydrological research, in both alluvial and bedrock settings, needs to focus on detailed reach-scale studies that aim to quantify autogenic responses before inferences can be made concerning possible allogenic drivers such as climate and land-use change. The issue of self-organized criticality in fluvial systems is likely to place greater emphasis on bedrock palaeoflood records for investigating flood response to climatic variability as in such settings the link between the sedimentary evidence and flood magnitude is clearer and less susceptible to SOC. Future fluvial palaeohydrology research, whether in alluvial or bedrock settings, will need robust geochronological frameworks underpinned by Bayesian age models.

\section{Conclusions}

In this paper we have presented a new Bayesian age modelling methodology for the analysis of Holocene palaeoflood records from bedrock gorge reaches. Previous studies have focused on radiocarbon frequency approaches (e.g. Ely, 1997; Thorndycraft and Benito, 2006), which lose important hydrologic and geomorphic information. The methodology outlined here, and illustrated in Figure 1, ensures that maximum use is made of the specific flood information available in palaeoflood studies. The methodology was applied to three published studies in Spain (from the Guadalentín, Tagus and Llobregat river basins), chosen for their range of geomorphic settings and varying degrees of geochronological control. The key features of the approach are the ability to model ages for undated sediments and the creation of flood magnitude-frequency plots through the incorporation of discharge data from hydraulic modelling. The benefits of the Bayesian approach are demonstrated, not only in terms of the modelled ages for the undated sedimentary units and the resulting flood magnitude-frequency plots (e.g. Figure 4) but also with regards the transparency of the approach. Given the wider theoretical issues of using fluvial sediments to elucidate river response to past climatic variability, in particular the recognition of selforganised criticality in fluvial systems (Van De Wiel and Coulthard, 2010), there is an ever greater need to refine geochronological methods and Bayesian age modelling should be one approach that is applied in alluvial and bedrock studies alike.

\section{Acknowledgements}

The authors are grateful to Dr Ian Matthews and Dr Simon Blockley (both at Royal Holloway, University of London) for discussions on the Bayesian age models. The comments of Vic Baker (University of Arizona) helped improve the original manuscript.

\section{Funding}

The original palaeoflood studies were funded by the Spanish Committee for Science and Technology (CICYT) grant HID99-0850 (Tagus) and the European Commission through the SPHERE project, grant EVG1-CT-1999-00010 (Guadalentín and Llobregat), with continued support through the Spanish Ministry of Science and Technology (CICYT) grant GL2008-06474-CO2-01.

\section{References}

Baker VR (1987) Paleoflood hydrology and extraordinary flood events. Journal of Hydrology 96: 79-99.
Baker VR, Webb RH and House PK (2002) The scientific and societal value of paleoflood hydrology. In: House PK, Webb RH, Baker VR and Levish DR (eds) Ancient Floods, Modern Hazards: Principles and Applications of Paleoflood Hydrology. Washington: American Geophysical Union, Water Science and Application 5, 1-19.

Barriendos M and Martín-Vide J (1998) Secular climatic oscillations as indicated by catastrophic floods in the Spanish mediterranean coastal area (14th-19th centuries). Climatic Change 38: 473-491.

Benito G and Thorndycraft VR (2005) Palaeoflood hydrology and its role in applied hydrological sciences. Journal of Hydrology 313: 3-15.

Benito G, Lang M, Barriendos M, Llasat MC, Francés F, Ouarda T et al. (2004) Use of systematic, palaeoflood and historical data for the improvement of flood risk estimation: Review of scientific methods. Natural Hazards 31: 623-643.

Benito G, Rico M, Sánchez-Moya Y, Sopeña A, Thorndycraft VR and Barriendos M (2010) Late Holocene climatic variability and land-use change impacts on flood hydrology (Guadalentin River, SE Spain). Global and Planetary Change 70: 53-63.

Benito G, Sánchez-Moya Y and Sopeña A (2003a) Sedimentology of high-stage flood deposits of the Tagus River, Central Spain. Sedimentary Geology 157: 107-132.

Benito G, Sopeña A, Sánchez Y, Machado MJ and Pérez González A (2003b) Palaeoflood record of the Tagus river (Central Spain) during the Late Pleistocene and Holocene. Quaternary Science Reviews 22: 1737-1756.

Benito G, Thorndycraft VR, Rico MT, Sánchez-Moya Y, Sopeña A, Botero BA et al. (2011) Hydrological response of a dryland ephemeral river to southern African climatic variability during the last millennium. Quaternary Research 75: 471-482.

Bronk Ramsey C (2008a) OxCal 4.0 Manual, Online web resource. Oxford, http://c14.arch.ox.ac.uk

Bronk Ramsey C (2008b) Deposition models for chronological records. Quaternary Science Reviews 27: 42-60.

Burr GS (2007) Radiocarbon dating: Causes of temporal variations. In: Elias SE (ed.) Encyclopedia of Quaternary Science. Amsterdam: Elsevier, 2931-2941.

Casas A, Benito G, Thorndycraft VR and Rico M (2006) The topographic data source of digital terrain models as a key element in the accuracy of hydraulic flood modelling. Earth Surface Processes and Landforms 31: 444-456.

Chiverrell RC, Foster GC, Thomas GSP and Marshall P (2009b) Sediment transmission and storage: The implications for reconstructing landform development. Earth Surface Processes and Landforms 35: 5-15.

Chiverrell RC, Foster GC, Thomas GSP, Marshall P and Hamilton D (2009a) Robust chronologies for landform development. Earth Surface Processes and Landforms 34: 319-328.

Chiverrell RC, Thorndycraft VR and Hoffmann TO (2011) Cumulative probability functions and their role in evaluating the chronology of geomorphological events during the Holocene. Journal of Quaternary Science 26: 76-85.

Cook GT and van der Plicht J (2007) Radiocarbon dating: Conventional method. In: Elias SE (ed.) Encyclopedia of Quaternary Science. Amsterdam: Elsevier, 2899-2911.

Ely LL (1997) Response of extreme floods in the southwestern United States to climatic variations in the late Holocene. Geomorphology 19: 175-201.

Ely LL, Enzel Y, Baker VR and Cayan DR (1993) A 5000-year record of extreme floods and climate change in the southwestern United States. Science 262: 410-412.

Johnstone E, Macklin MG and Lewin J (2006) The development and application of a database of radiocarbon-dated Holocene fluvial deposits in Great Britain. Catena 66: 14-23.

Jull AJT (2007) Radiocarbon dating: AMS method. In: Elias SE (ed.) Encyclopedia of Quaternary Science. Amsterdam: Elsevier, 2911-2918.

Knox JC (2000) Sensitivity of modern and Holocene floods to climate change. Quaternary Science Reviews 19: 439-457.

Kochel RC and Baker VR (1988) Paleoflood analysis using slack water deposits. In: Baker VR, Kochel RC and Patton PC (eds) Flood Geomorphology. USA: John Wiley \& Sons Ltd, 357-376.

Levish DR (2002) Paleohydrological bounds - non-exceedance information for flood hazard assessment. In: House PK, Webb RH, Baker VR and Levish DR (eds) Ancient Floods, Modern Hazards: Principles and Applications of Paleoflood Hydrology. Washington, DC: American Geophysical Union, Water Science and Application 5, 175-190.

Llasat MC, Barriendos M, Barrera A and Rigo T (2005) Floods in Catalonia (NE Spain) since the 14th century: Climatological and meteorological aspects from historical documentary sources and old instrumental records. Journal of Hydrology 313: 32-47.

Macklin MG, Benito G, Gregory KJ, Johnstone E, Lewin J, Soja R et al. (2006) Past hydrological events reflected in the Holocene fluvial history of Europe. Catena 66: 145-154. 
Macklin MG, Jones AF and Lewin J (2010) River response to rapid Holocene environmental change: Evidence and explanation in British catchments. Quaternary Science Reviews 29: 1555-1576.

Redmond KT, Enzel Y, House PK and Biondi F (2002) Climate variability and flood frequency at decadal to millennial time scales. In: House PK, Webb RH, Baker VR and Levish DR (eds) Ancient Floods, Modern Hazards: Principles and Applications of Paleoflood Hydrology. Washington: American Geophysical Union, Water Science and Application $5,21-45$.

Rittenour TM (2008) Luminescence dating of fluvial deposits: Applications to geomorphic, palaeoseismic and archaeological research. Boreas 37: 613-635.

Robson AJ (2002) Evidence for trends in UK flooding. Philosophical Transactions: Mathematical, Physical and Engineering Sciences 360: 1327-1343.

Rodnight H, Duller GAT, Tooth S and Wintle AG (2005) Optical dating of a scroll bar sequence on the Klip River, South Africa, to derive the lateral migration rate of a meander bend. The Holocene 15: 802-811.

Rodnight H, Duller GAT, Wintle AG and Tooth S (2006) Assessing the reproducibility and accuracy of optical dating of fluvial deposits. Quaternary Geochronology 1: 109-120.

Scott EM (2007) Radiocarbon dating: Sources of error. In: Elias SE (ed.) Encyclopedia of Quaternary Science. Amsterdam: Elsevier, 2918-2923.

Sheffer NA, Enzel Y, Benito G, Grodek T, Poart N, Lang M et al. (2003) Paleofloods and historical floods of the Ardeche River, France. Water Resources Research 39: 1376.
Sheffer NA, Rico M, Enzel Y, Benito G and Grodek T (2008) The palaeoflood record of the Gardon River, France: A comparison with the extreme 2002 flood event. Geomorphology 98: 71-83.

Thorndycraft VR and Benito G (2006) The Holocene fluvial chronology of Spain: Evidence from a newly compiled radiocarbon database. Quaternary Science Reviews 25: 223-234.

Thorndycraft VR, Benito G, Rico M, Sánchez-Moya Y, Sopeña A and Casas A (2005) A long-term flood discharge record derived from slackwater flood deposits of the Llobregat River, NE Spain. Journal of Hydrology 313: 16-31.

Trumbore SE (2000) Radiocarbon geochronology. In: Noller JS, Sowers JM and Lettis WR (eds) Quaternary Geochronology: Methods and Applications. Washington: American Geophysical Union, 41-60.

Van De Wiel MJ and Coulthard TJ (2010) Self-organized criticality in river basins: Challenging sedimentary records of environmental change. Geology 38: 87-90.

van der Plicht J (2007) Radiocarbon dating: Variations in atmospheric ${ }^{14} \mathrm{C}$. In: Elias SE (ed.) Encyclopedia of Quaternary Science. Amsterdam: Elsevier, 2924-2931.

Van Geel B, Van der Plicht J, Kilian MR, Klaver ER, Kouwenberg JHM, Ressen $\mathrm{H}$ et al. (1998) The sharp rise of d14C at ca. 800 cal. BC. Possible causes, related climatic teleconnections and the impact on human environments. Radiocarbon 40: 335-350.

Webb RH and Jarrett RD (2002) One-dimensional estimation techniques for discharges of paleofloods and historical floods. In: House PK, Webb RH, Baker VR and Levish DR (eds.) Ancient Floods, Modern Hazards: Principles and Applications of Paleoflood Hydrology. Washington: American Geophysical Union, Water Science and Application 5, 111-126. 